\title{
Evaluation of Brain Nuclear Medicine Imaging Tracers in a Murine Model of Sepsis-Associated Encephalopathy
}

\author{
Dávid Szöllősi®, ${ }^{2}$ Nikolett Hegedűs, ${ }^{2}$ Dániel S. Veres, ${ }^{2}$ Ildikó Futó, ${ }^{2}$ Ildikó Horváth, ${ }^{2}$ \\ Noémi Kovács, ${ }^{1}$ Bernadett Martinecz, ${ }^{3}$ Ádám Dénes, ${ }^{3}$ Daniel Seifert, ${ }^{5}$ Ralf Bergmann, ${ }^{4}$ \\ Ondřej Lebeda, ${ }^{5}$ Zoltán Varga, ${ }^{2,6}$ Zoltán Kaleta, ${ }^{7}$ Krisztián Szigeti, $^{2}$ Domokos Máthé ${ }^{1}$ \\ ${ }^{1}$ CROmed Translational Research Centers, Budapest, H-1047, Hungary \\ ${ }^{2}$ Department of Biophysics and Radiation Biology, Semmelweis Univ, Budapest, H-1094, Hungary \\ ${ }^{3}$ Laboratory of Neuroimmunology, Institute of Experimental Medicine, Budapest, Hungary \\ ${ }^{4}$ Helmholz-Zentrum Dresden-Rossendorf, Radiopharmazie Radiopharmaceutische Biologie, Dresden, Germany \\ ${ }^{5}$ Nuclear Physics Institute of the CAS, CZ 250 68, Rez, Czech Republic \\ ${ }^{6}$ Biological Nanochemistry Research Group, Institute of Materials and Environmental Chemistry, Research Centre for Natural Sciences, \\ Hungarian Academy of Sciences, Budapest, Hungary \\ ${ }^{7}$ Progressio Fine Chemical Engineering Ltd, Székesfehérvár, Hungary
}

\begin{abstract}
Purpose: The purpose of this study was to evaluate a set of widely used nuclear medicine imaging agents as possible methods to study the early effects of systemic inflammation on the living brain in a mouse model of sepsis-associated encephalopathy (SAE). The lipopolysaccharide (LPS)-induced murine systemic inflammation model was selected as a model of SAE.

Procedures: C57BL/6 mice were used. A multimodal imaging protocol was carried out on each animal $4 \mathrm{~h}$ following the intravenous administration of LPS using the following tracers: [99m Tc][2,2-dimethyl-3-[(3E)-3-oxidoiminobutan-2-yl]azanidylpropyl]-[(3E)-3-hydroxyiminobutan2-yl]azanide $\left.\left({ }^{99 \mathrm{~m}} \mathrm{Tc}\right] \mathrm{HMPAO}\right)$ and ethyl-7-[ $\left.\left.{ }^{125}\right]\right]$ iodo-5-methyl-6-oxo-4H-imidazo[1,5-a][1,4]benzodiazepine-3-carboxylate ([ $\left.{ }^{125} \mid\right]$ iomazenil) to measure brain perfusion and neuronal damage, respectively; 2-deoxy-2- $\left[{ }^{18} \mathrm{~F}\right]$ fluoro-D-glucose $\left(\left[{ }^{18} \mathrm{~F}\right] \mathrm{FDG}\right)$ to measure cerebral glucose uptake. We assessed microglia activity on another group of mice using 2-[6-chloro-2-(4-[25]]iodophenyl)-imidazo[1,2-a]pyridin-3-yl]- $N$-ethyl- $N$-methyl-acetamide ([ ${ }^{125}$ I]CLINME). Radiotracer uptakes were measured in different brain regions and correlated. Microglia activity was also assessed using immunohistochemistry. Brain glutathione levels were measured to investigate oxidative stress.

Results: Significantly reduced perfusion values and significantly enhanced $\left[{ }^{18} \mathrm{~F}\right] \mathrm{FDG}$ and $\left[{ }^{125}\right.$ I]CLINME uptake was measured in the LPS-treated group. Following perfusion compensation, enhanced $\left[{ }^{125} \mid\right]$ iomazenil uptake was measured in the LPS-treated group's hippocampus and cerebellum. In this group, both $\left[{ }^{18} \mathrm{~F}\right] \mathrm{FDG}$ and $\left.\left[{ }^{125}\right]\right]$ iomazenil uptake showed highly negative
\end{abstract}

Krisztián Szigeti and Domokos Máthé contributed equally to this work. Electronic supplementary material The online version of this article (https:// doi.org/10.1007/s11307-018-1201-3) contains supplementary material, which is available to authorized users. 
correlation to perfusion measured with $\left({ }^{99 \mathrm{~m}} \mathrm{Tc}\right] \mathrm{HMPAO}$ uptake in all brain regions. No significant differences were detected in brain glutathione levels between the groups. The CD45 and P2Y12 double-labeling immunohistochemistry showed widespread microglia activation in the LPStreated group.

Conclusions: Our results suggest that $\left[{ }^{125} \mathrm{I}\right] \mathrm{CLINME}$ and $\left[{ }^{99 \mathrm{~m}} \mathrm{Tc}\right] \mathrm{HMPAO}$ SPECT can be used to detect microglia activation and brain hypoperfusion, respectively, in the early phase (4 h post injection) of systemic inflammation. We suspect that the enhancement of $\left[{ }^{18} \mathrm{~F}\right] \mathrm{FDG}$ and $\left[{ }^{125} \mid\right]$ iomazenil uptake in the LPS-treated group does not necessarily reflect neural hypermetabolism and the lack of neuronal damage. They are most likely caused by processes emerging during neuroinflammation, e.g., microglia activation and/or immune cell infiltration.

Key words: Systemic infection, Neuroinflammation, Microglia activation, LPS, [ $\left.{ }^{99 \mathrm{~m}} \mathrm{Tc}\right] \mathrm{HMPAO}$, $\left.\left[{ }^{18} \mathrm{~F}\right] \mathrm{FDG},\left[{ }^{125}\right]\right]$ iomazenil, $\left.\left[{ }^{125}\right]\right]$ CLINME, SPECT/CT, PET/MRI

\section{Introduction}

Sepsis-associated encephalopathy (SAE) is a devastating complication of severe acute systemic inflammation. It causes both acute and long-lasting neurological dysfunction and contributes to the mortality of patients with sepsis [1]. Current clinical approaches are mainly based on the earliest possible diagnosis and treatment of the systemic inflammation, but our knowledge of the pathophysiological processes overwhelming the brain at this early stage of sepsis is far from complete. Understanding these processes could lead to the development of disease-specific diagnostic and therapeutic approaches that could potentially protect the brain from systemic inflammation and improve mortality.

Much of our current knowledge of SAE has been gathered from animal studies [2]. One of the most important animal models is the lipopolysaccharide (LPS)-induced murine systemic inflammation model. Following the systemic administration of LPS, the mouse brain exhibits a variety of acute and long-lasting alterations including the elevation of inflammatory cytokines [3-7], microglia activation $[8,9]$, neuron damage [3], altered neurotransmission [10], oxidative stress $[3,11]$, blood-brain barrier changes [3, 12] vascular adhesion [13], or invasion of immune cells [14]. Similarities have been found between this mouse model and human SAE [12, 15-18], making it also a model of murine SAE. A favorable approach to investigating the brain during systemic inflammation is multimodal nuclear medicine imaging $[19,20]$. This approach could provide a means to investigate the little-known spatiotemporal distribution and correlations of multiple parameters related to pathophysiology. Brain region-specific connections between the pathophysiologic processes also provide important implications for neuroinflammation in general.

Even if a radiopharmaceutical is highly specific to a certain target, its biodistribution may not be dependent on a single biological process. In turn, many different pathophysiological factors can influence uptake by the specified target (e.g., an increase in 2-deoxy-2-[ $\left[{ }^{18} \mathrm{~F}\right]$ fluoro-D-glucose $\left(\left[{ }^{18} \mathrm{~F}\right] \mathrm{FDG}\right)$ uptake could be caused by a wide variety of processes) [21]. Parameters measured in healthy brain or during neuroinflammation could be determined by quite different disease-specific processes.

The aim of this study was to assess whether quantitative multimodal in vivo imaging with a set of widely used radiotracers (Table 1) could be used to investigate a set of brain alterations and their region-specific connections associated to the early phase of neuroinflammation induced by systemic LPS injection in mice.

We investigated the following: brain perfusion with $\left[{ }^{99 \mathrm{~m}} \mathrm{Tc}\right] \mathrm{HMPAO}$ single photon emission computed tomography (SPECT), brain glucose metabolism with $\left[{ }^{18} \mathrm{~F}\right] \mathrm{FDG}$ positron emission tomography (PET), neuron damage with the central benzodiazepine receptor ligand $\left[{ }^{125} \mathrm{I}\right]$ iomazenil SPECT, and microglia activation with the $18 \mathrm{kDa}$ translocator protein (TSPO, or, peripheral benzodiazepine receptor, PBR) ligand $\left[{ }^{125} \mathrm{I}\right]$ CLINME SPECT. We described microglia activation with immunohistochemistry (IHC) and oxidation state by a fluorometric ex vivo glutathione assay. These methods have been validated for the respective alterations in multiple models (see references in Table 1).

\section{Materials and Methods}

\section{Summary of the Experiments}

The experiments are summarized in Fig. 1a. $\left[{ }^{99 \mathrm{~m}} \mathrm{Tc}\right] \mathrm{HMPAO}$ and $\left[{ }^{125} \mathrm{I}\right]$ iomazenil dual SPECT, and $\left[{ }^{18} \mathrm{~F}\right]$ FDG PET were carried out on LPS-treated and control animals and the correlations of the results were computed. These animals were later used for the ex vivo glutathione assay. $\left[{ }^{125} \mathrm{I}\right]$ CLINME SPECT and IHC measurements were completed on different animals due to the methodical incompatibility of these assays with previous ones. These two measurements were used to study the variability of brain region-specific microglial response. MR images were used to segment the brain into 3D volumes of interest (cerebru$\mathrm{m}$-indicating the whole brain without cerebellum, cerebellum, cerebral cortex, and hippocampus) using a connected threshold algorithm (Fig. 1b, c). 
Table 1. A summary of the radiotracers and modalities used in this study

\begin{tabular}{|c|c|c|c|}
\hline Radiotracer & Abbreviation & Modality & Putative alteration/process \\
\hline $\begin{array}{l}\text { [99m Tc][2,2-dimethyl-3-[(3E)-3-oxidoiminobutan-2-yl]azanidylpropyl]-[(3E)-3- } \\
\text { hydroxyiminobutan-2-yl]azanide }\end{array}$ & {$\left[{ }^{99 \mathrm{~m}} \mathrm{Tc}\right] \mathrm{HMPAO}$} & SPECT & Brain perfusion [22] \\
\hline ethyl 7-[ ${ }^{15}$ I]iodo-5-methyl-6-oxo-4H-imidazol[1,5-a][1,4]benzodiazepine-3-carboxylate & {$\left[{ }^{125}\right.$ I] iomazenil } & SPECT & $\begin{array}{l}\text { Neuronal damage/apoptosis } \\
{[23-26]}\end{array}$ \\
\hline 2-[6-chloro-2-(4-[ $\left.{ }^{125} I\right]$ iodophenyl)-imidazo[1,2-a]pyridin-3-yl]-N-ethyl-N-methyl-acetamide & {$\left[{ }^{125} \mathrm{I}\right] \mathrm{CLINME}$} & SPECT & Microglia activation [27] \\
\hline 2-deoxy-2-[ $\left[{ }^{18} \mathrm{~F}\right]$ fluoro-D-glucose & {$\left[{ }^{18} \mathrm{~F}\right] \mathrm{FDG}$} & PET & Cerebral glucose uptake [28] \\
\hline
\end{tabular}

SPECT: single photon emission computed tomography, PET: positron emission tomography.

Glutathione levels were determined ex vivo using a colorimetric assay. Microscopically, resting (highly ramified, P2Y12+ cells with low CD45 signal [29-32]) and activated $\left(\mathrm{P} 2 \mathrm{Y} 12+, \mathrm{CD} 45_{\text {low }}\right.$ ramified cells with thickened processes and enlarged body) microglia cells were counted. Blood-derived leukocytes (CD45-positive, round shape cells with predominantly perivascular location) $[32,33]$ were excluded from analysis. The correlation coefficients of measured nuclear medicine parameters per brain regions in vivo were calculated with correlation analysis (GraphPadPrism6.0, GraphPad Software Inc., La Jolla, CA, USA).

Experimental details are further described in the Electronic Supplementary Material (ESM) under the "Materials and Methods" section.

a Neostigmine inj. ( $\mathrm{t}=0 \mathrm{~min}$ )

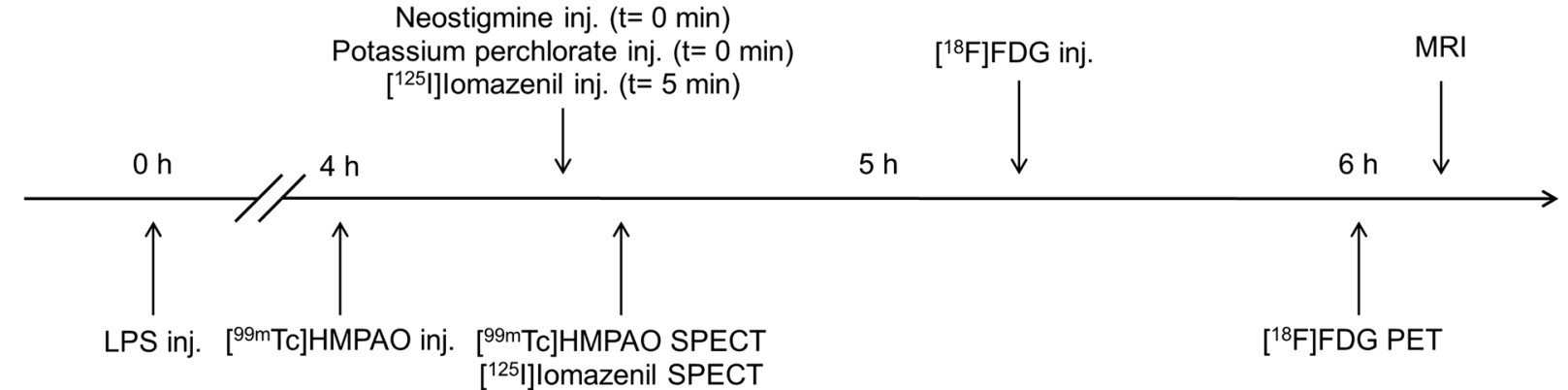

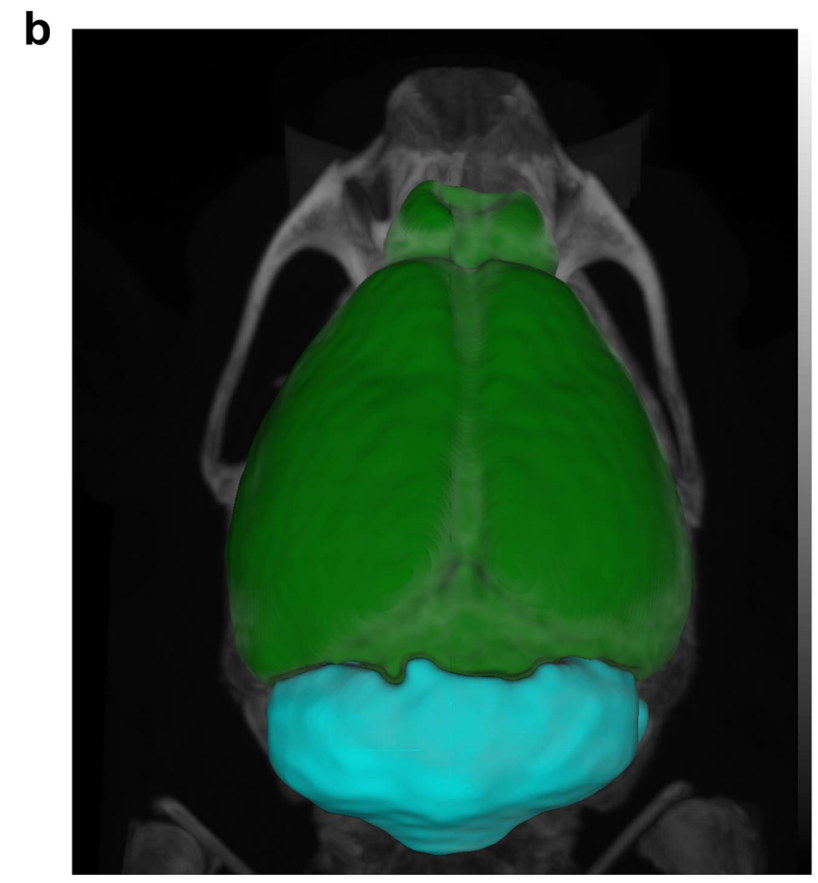

GREEN=Cerebrum

TURQUOISE=Cerebellum

c

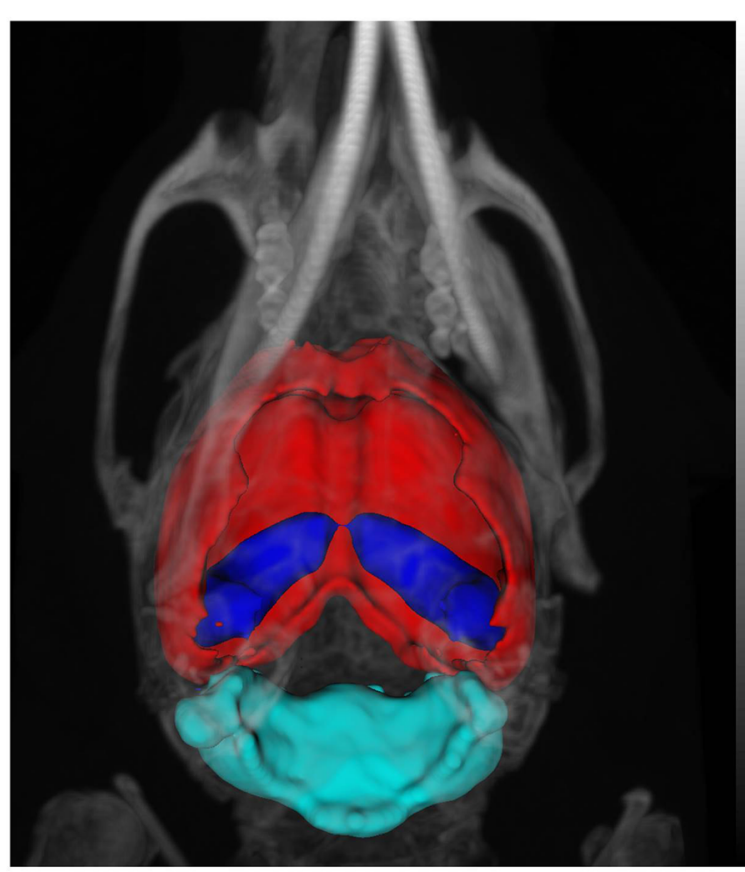

RED=Cortex
BLUE=Hippocampus

Fig. 1 Illustration of the methods. a Experimental protocol for in vivo measurements. b Dorsal view of MRI coregistration with CT showing the segmented 3D brain regions. c Ventral view of the same VOls (volumes of interest). Representing the cerebrum (green: this entity includes the whole brain without cerebellum), cerebellum (turquoise), cortex (red), and hippocampus (blue). 
a

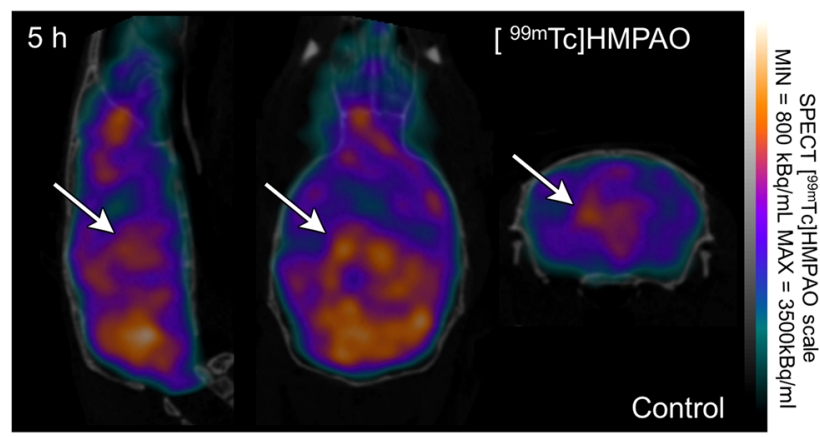

C

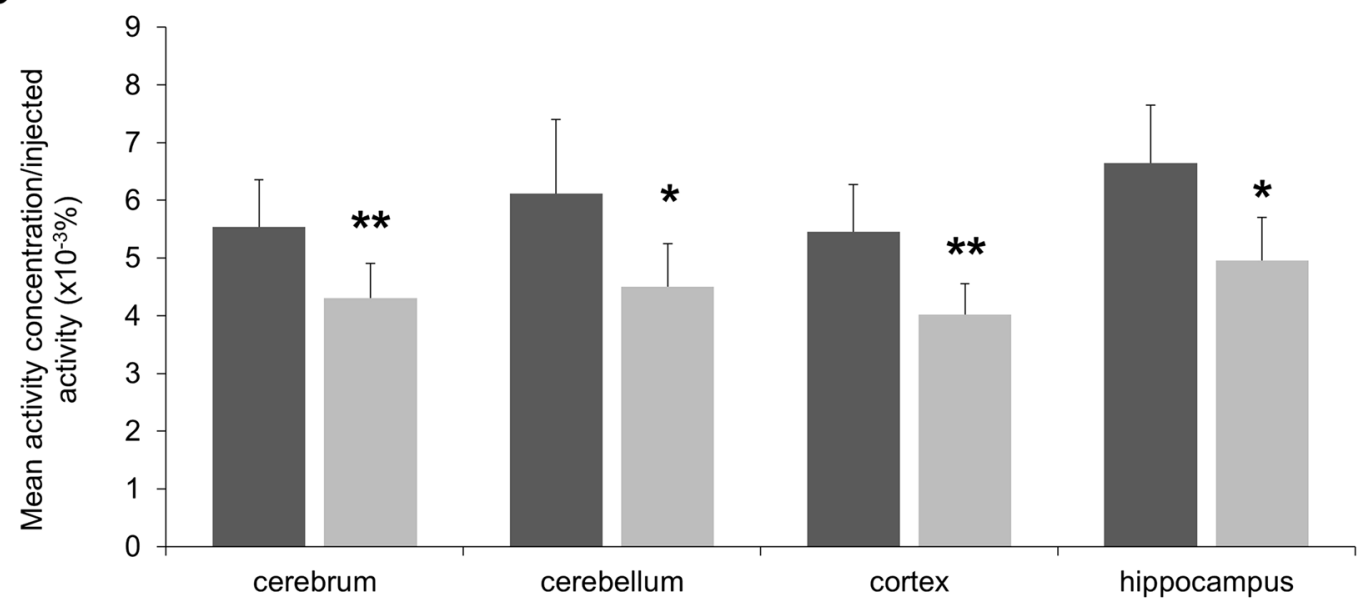

b

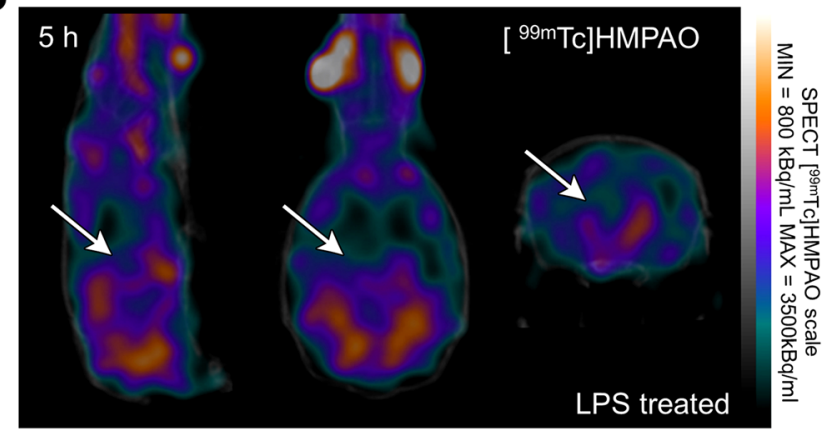

- Control $\square$ LPS treated

${ }^{*} p<0.05,{ }^{* *} p<0.01,{ }^{* * *} p<0.001$; One-sided permutation test

Fig. 2 SPECT imaging reveal decreased perfusion after LPS injection. Cerebral blood perfusion was measured by [ $\left.{ }^{99 \mathrm{~m}} \mathrm{Tc}\right] \mathrm{HMPAO}$. SPECT coregistration with computed tomography (CT) showing [ $\left.{ }^{99 \mathrm{~m}} \mathrm{Tc}\right] \mathrm{HMPAO}$ uptake in $\mathbf{a}$ control and $\mathbf{b}$ LPS-treated animals. Arrows indicate areas where the difference in radiotracer uptakes between the two groups is observable. c $\left[{ }^{99 m} \mathrm{Tc}\right] \mathrm{HMPAO}$ uptake is significantly reduced $5 \mathrm{~h}$ after the LPS injection in all examined brain regions (cerebrum: indicates the whole brain without cerebellum, cerebellum, cortex, and hippocampus; ${ }^{*} p \leq 0.05 ;{ }^{* \star} p<0.01 ;{ }^{\star \star *} p<0.001-$ one-sided permutation test).

\section{Perfusion Compensation and Data Analysis}

For perfusion compensation $\left[{ }^{125} \mathrm{I}\right]$ iomazenil uptake was divided by the same animals' simultaneously measured $\left[{ }^{99 \mathrm{~m}} \mathrm{Tc}\right] \mathrm{HMPAO}$ uptake in each region to eliminate the inflammation-related relative blood flow changes. Normality of data sets was assessed with the Kolmogorov-Smirnov test. Data from in vivo measurements (PET and SPECT scans) were analyzed with the one-sided permutation test. This test is a conditional statistical procedure where the conditioning is with respect to the observed data set [34]. The correlation coefficients per brain regions were calculated with correlation analysis. Data from immunohistochemical studies were analyzed with unpaired $t$ tests (GraphPadPrism6.0, GraphPad Software Inc., La Jolla, CA, USA). In all cases, $p$ value $\leq 0.05$ was considered as statistically significant.

\section{Results}

$\left.\sum^{99 m} T c\right] H M P A O$ SPECT Imaging

The results of $\left[{ }^{99 \mathrm{~m}} \mathrm{Tc}\right] \mathrm{HMPAO}$ SPECT measurements are illustrated in Fig. 2a, b. In every segmented brain region (cerebrum, cerebellum, cerebral cortex, and hippocampus), significantly reduced $(p<0.05)\left[{ }^{99 \mathrm{~m}} \mathrm{Tc}\right] \mathrm{HMPAO}$ uptake was observed in the LPS-treated group compared to the control (Fig. 2c).

\section{${ }^{125}$ I]iomazenil-SPECT Imaging}

The results of $\left[{ }^{125} \mathrm{I}\right]$ iomazenil SPECT measurements are illustrated in Fig. 3a, b. Perfusion compensation resulted in significantly enhanced $\left[{ }^{125} \mathrm{I}\right]$ iomazenil uptake values in the LPS-treated group's cerebellum and hippocampus compared 
a

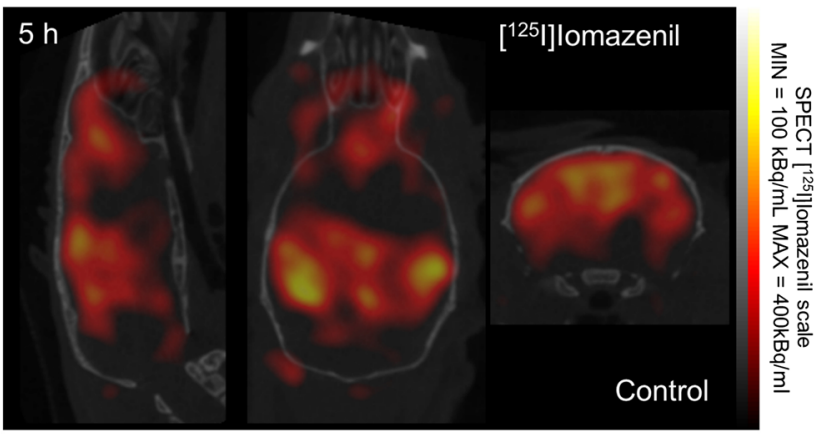

b

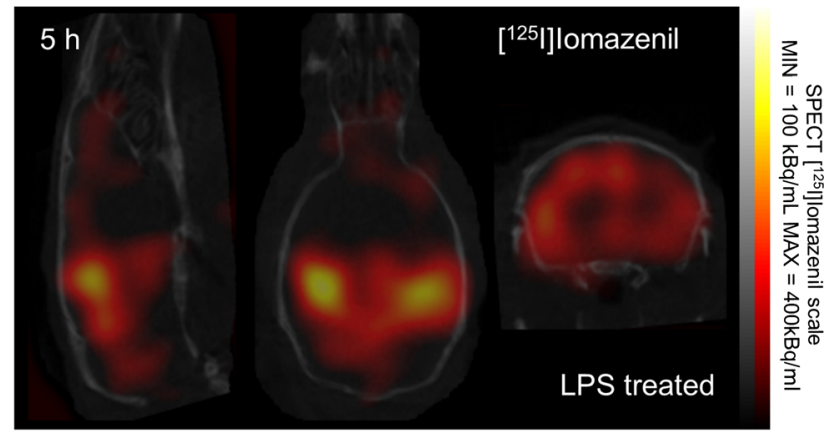

- Control $\square$ LPS treated

C

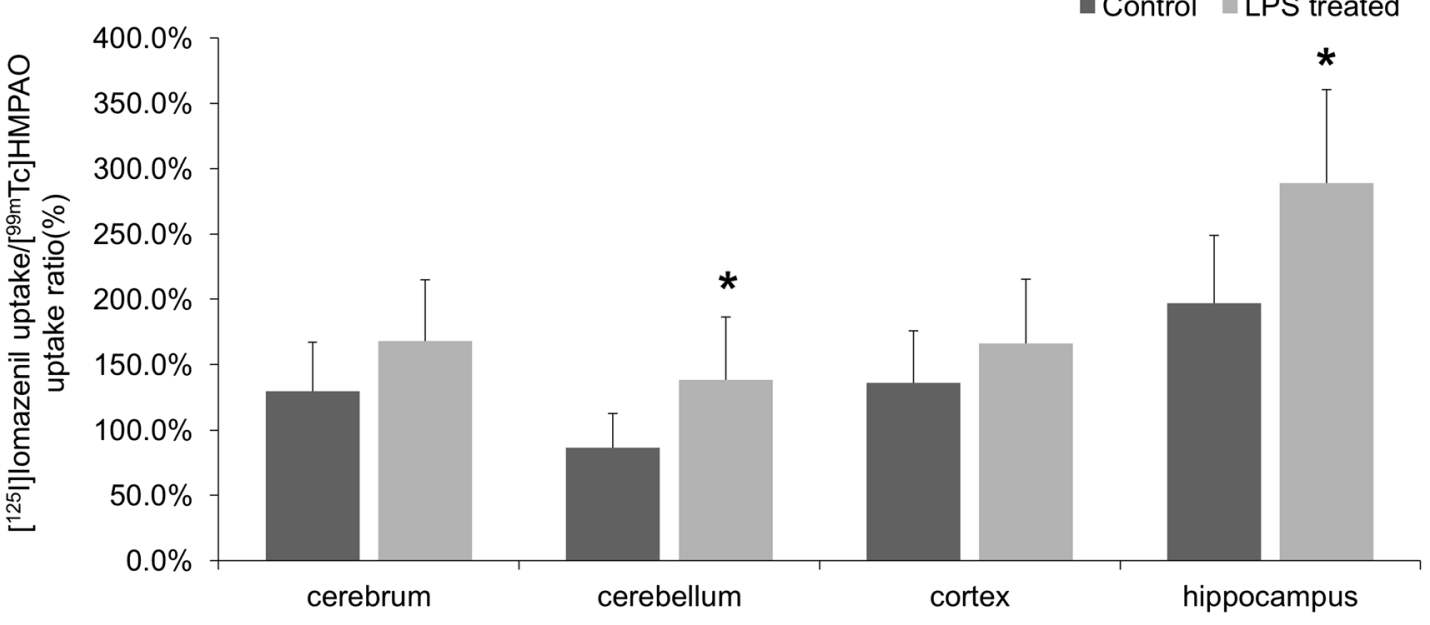

${ }^{*} p<0.05,{ }^{* *} p<0.01,{ }^{* * *} p<0.001$; One-sided permutation test

Fig. 3 SPECT imaging of $\left[{ }^{125}\right.$ I] iomazenil following LPS injection. SPECT coregistration with CT showing iomazenil uptake in a control and b LPS-treated animals. $\mathbf{c}\left[{ }^{125}\right.$ l]iomazenil uptake is significantly increased $5 \mathrm{~h}$ after the LPS injection in cerebellum and hippocampus ( ${ }^{*} p \leq 0.05$-one-sided permutation test). Relevant changes were also observed and measured in the area of cerebrum and cortex but these differences were not significant $(p=0.095, p=0.138$, respectively).

to the control. Relevant changes were seen in the cortex and the whole cerebrum but these differences were not significant (Fig. 3c).

\section{$\left[{ }^{18}\right.$ F]FDG PET Imaging}

$\left[{ }^{18} \mathrm{~F}\right]$ FDG measurements were able to visualize early changes of metabolic activity following LPS injection (Fig. 4a, b, Supplementary Fig. 1). In almost all segmented brain regions (cerebrum, cerebellum, and cerebral cortex), significantly enhanced $(p<0.05)\left[{ }^{18} \mathrm{~F}\right] \mathrm{FDG}$ uptake was measured in the treated group compared to the control (Fig. 4c).

\section{[ ${ }^{125}$ I]CLINME-SPECT Imaging}

$\left[{ }^{125} \mathrm{I}\right]$ CLINME SPECT results are shown in Fig. 5a, b. Significantly enhanced $(p=0.05)$ uptake was observed in the cerebrum and marked, but not significant elevation in all other investigated brain areas (Fig. 5c).

\section{Correlation Studies}

The results of the correlation studies are listed in Table 2 and illustrated in Supplementary Fig. 2. In the LPStreated group, highly positive correlation was found between the uptake values of $\left[{ }^{18} \mathrm{~F}\right] \mathrm{FDG}$ and $\left[{ }^{125} \mathrm{I}\right]$ iomazenil while these values had a strong negative correlation with $\left[{ }^{99 \mathrm{~m}} \mathrm{Tc}\right] \mathrm{HMPAO}$ uptake in all investigated regions. In the control group, strong negative correlation coefficients were found between the uptake of $\left[{ }^{18} \mathrm{~F}\right] \mathrm{FDG}$ and $\left[{ }^{125} \mathrm{I}\right]$ iomazenil in the cerebrum, cortex, and hippocampus, while small positive correlation coefficients were detected in the cerebellum. This brain region showed highly negative correlation between the uptake values of $\left[{ }^{125} \mathrm{I}\right]$ iomazenil and $\left[{ }^{99 \mathrm{~m}} \mathrm{Tc}\right] \mathrm{HMPAO}$. Moderate 
a

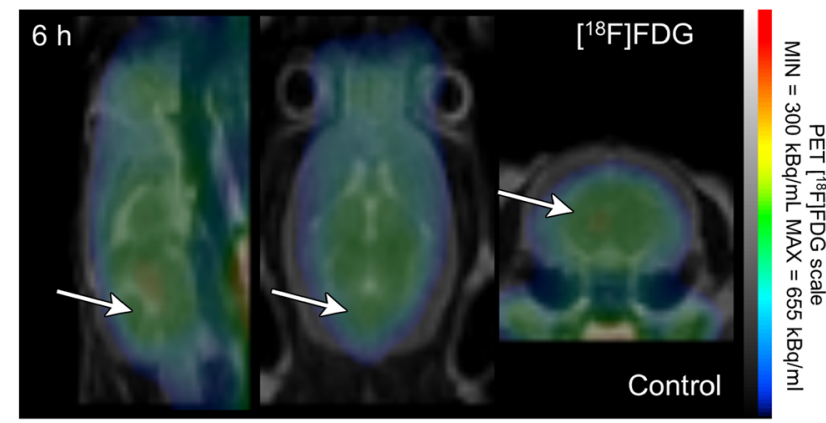

b

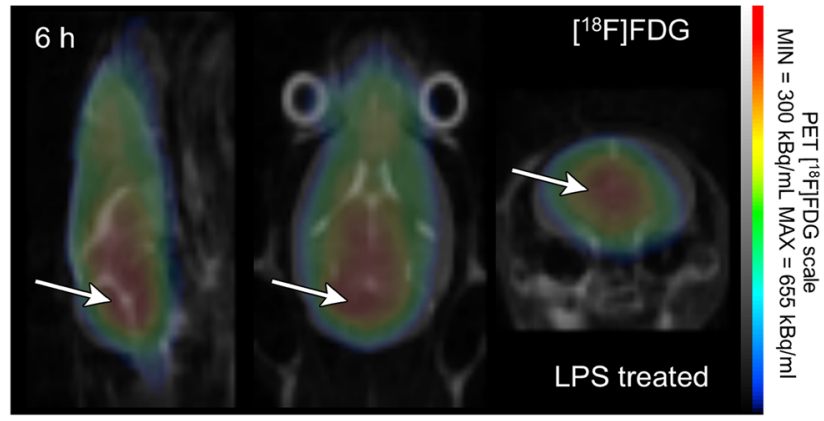

C

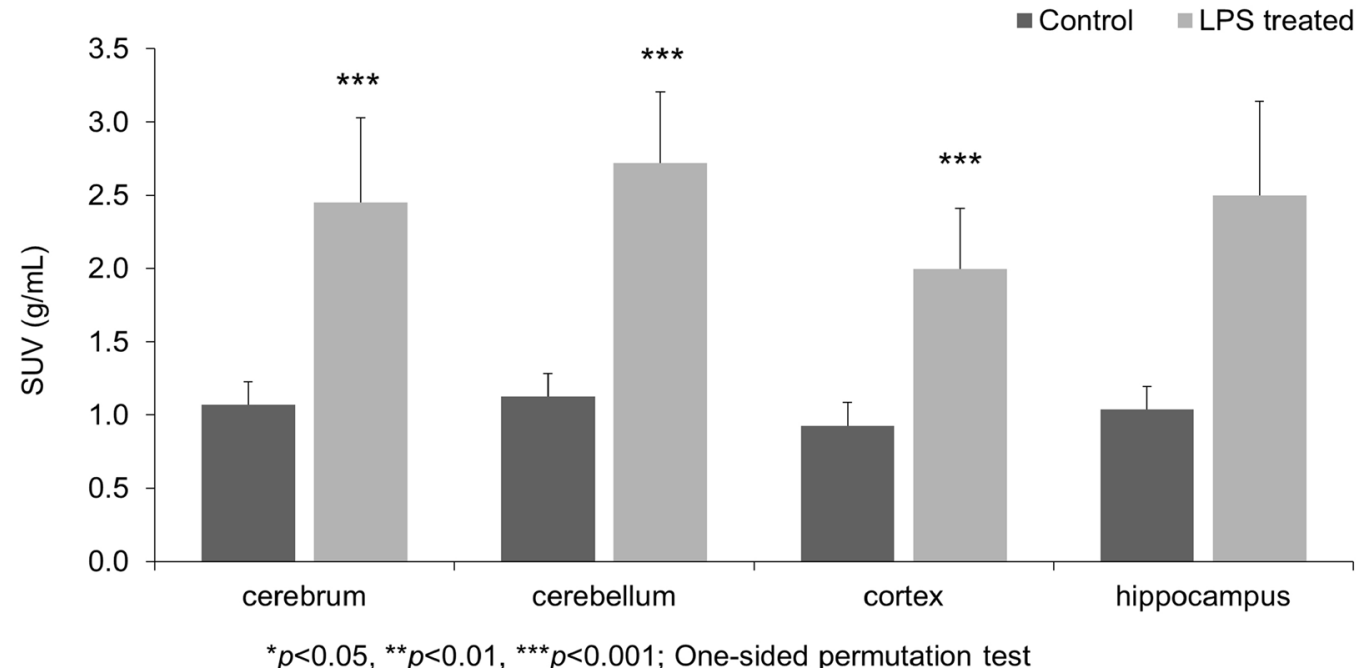

Fig. 4 PET imaging after LPS injection. Cerebral glucose transport and metabolism was measured by $\left[{ }^{18} \mathrm{~F}\right] \mathrm{FDG}$. Summarized PET signal during a $3 \mathrm{~min}$ time frame starting at $7 \mathrm{~min}$ post injection and ending at $10 \mathrm{~min}$ post injection of $\left[{ }^{18} \mathrm{~F}\right] \mathrm{FDG}$ is coregistered with CT showing $\left[{ }^{18} \mathrm{~F}\right] \mathrm{FDG}$ uptake in $\mathbf{a}$ control and $\mathbf{b}$ LPS-treated animals. Arrows indicate example areas where the difference in radiotracer uptakes between the two groups is visually discernable. $\mathbf{c}\left[{ }^{18} \mathrm{~F}\right] \mathrm{FDG}$ uptake is significantly increased $6 \mathrm{~h}$ after the LPS injection in cerebrum-defined as the whole brain without the cerebellum, cerebellum, and cortex. Relevant but not significant changes were registered in hippocampus $(p=0.057)\left({ }^{* \star} p<0.001\right.$-one-sided permutation test).

negative correlations were found between $\left[{ }^{18} \mathrm{~F}\right] \mathrm{FDG}$ and $\left[{ }^{99 \mathrm{~m}} \mathrm{Tc}\right] \mathrm{HMPAO}$ uptake values in the cortex and cerebellum.

Ex vivo glutathione level measurements showed no significant changes (for details see Supplementary Results).

\section{Immunohistochemistry}

The CD45 and P2Y12 double-labeling immunohistochemistry revealed microglial activation in response to systemic inflammation within $4 \mathrm{~h}$ after LPS administration (Fig. 6 a-d). Both the percentage of activated/all microglia (Fig. 6e) and the number of activated microglia/area (Fig. 6f) were significantly $(p<0.01)$ higher in the LPStreated group compared to the control group in all investigated regions.

\section{Discussion}

Tissue hypoperfusion is one of the hallmarks of sepsis syndrome and the brain is not an exception. In humans, decreased perfusion and impaired vascular autoregulation have been reported by multiple authors [17, 35-37]; however, this mechanism seems to be controversial [1]. Our dual SPECT measurement showed reduced $\left[{ }^{99 \mathrm{~m}} \mathrm{Tc}\right]$ HMPAO uptake in the brain of LPS-treated animals. Similar distributions were observed both in the control group and the LPS-treated group but the measured uptake quantities were significantly reduced in the latter (Fig. 2ac). The decreased perfusion might lead to metabolic imbalance and subsequent early and late phase adaptation of glucose transport and utilization by the brain's most metabolically active cells, astroglia and neurons.

Cerebral metabolic alterations have been previously suggested in SAE [38]. A decrease in cerebral glucose metabolism measured with $\left[{ }^{18}\right.$ F]FDG-PET after $24 \mathrm{~h}$ 
a

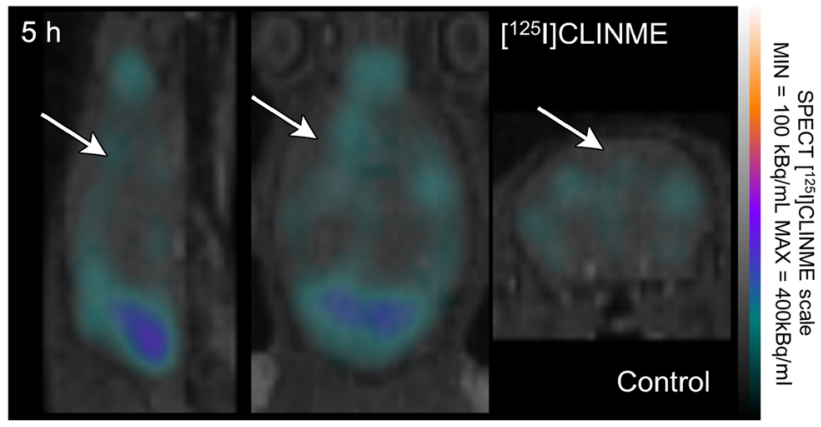

b

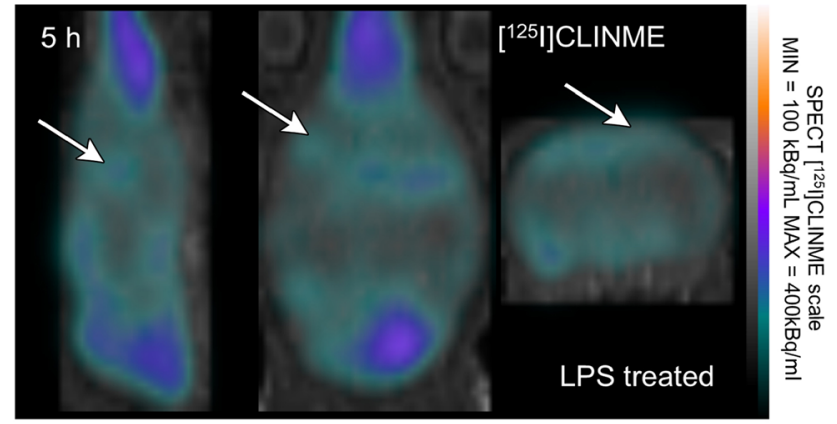

C

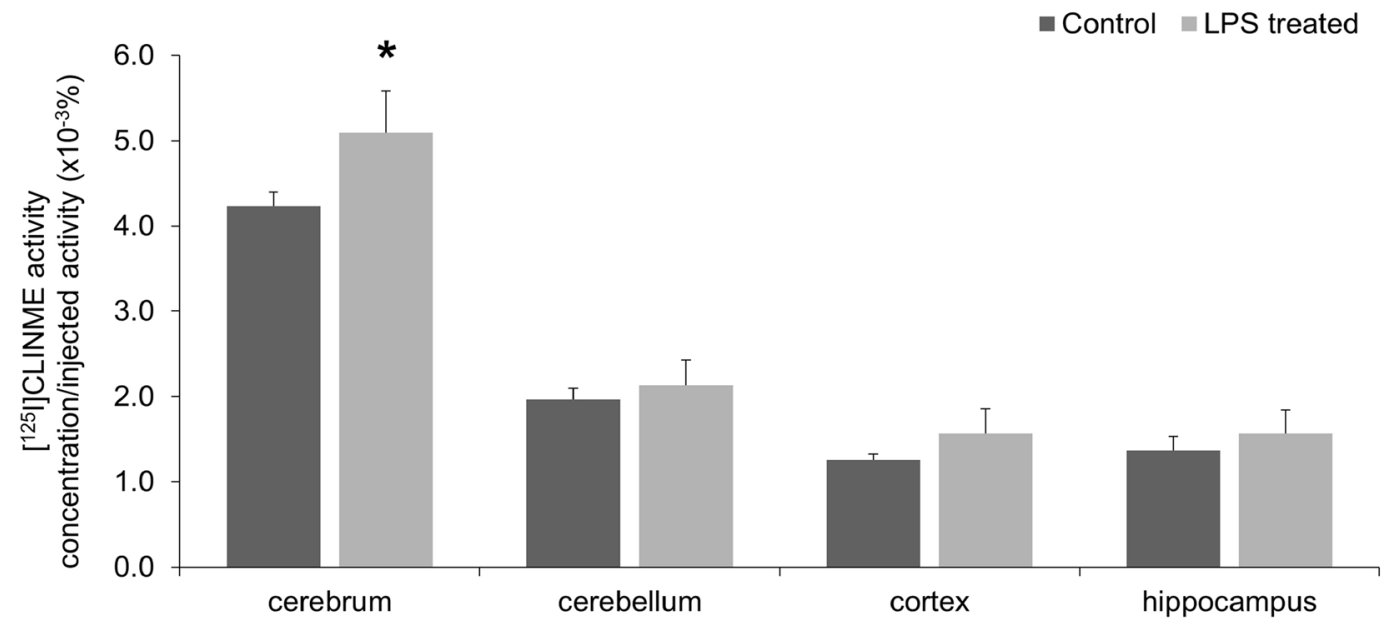

${ }^{*} p<0.05,{ }^{* *} p<0.01,{ }^{* * *} p<0.001$; One-sided permutation test

Fig. 5 Microglia activation was indirectly measured by ${ }^{125}$ I]CLINME uptake. SPECT coregistration with CT showing $\left[{ }^{125}\right.$ I]CLINME uptake changes after a LPS-induced neuroinflammation compared to $\mathbf{b}$ the control group. Arrows indicate example areas where the difference in radiotracer uptakes between the two groups is visually discernable. $\mathbf{c}\left[{ }^{125}\right.$ I]CLINME uptake is significantly increased $5 \mathrm{~h}$ after the LPS injection in the cerebrum $\left({ }^{*} p \leq 0.05\right.$-one-sided permutation test).

following LPS injection in rats has previously been reported [39]. In contrast, we have observed an early increase in $\left[{ }^{18} \mathrm{~F}\right] \mathrm{FDG}$ uptake $5 \mathrm{~h}$ following the induction of systemic inflammation in mice (Fig. 4a-c). Significantly enhanced $\left[{ }^{18} \mathrm{~F}\right] \mathrm{FDG}$ uptake values were observed in the cerebrum, cortex, and cerebellum $(p<0.05)$. Our measurements were

Table 2. The average correlation coefficients in LPS treated and control groups.

\begin{tabular}{|c|c|c|c|}
\hline Brain region & Correlated tracer uptake values & Control & LPS treated \\
\hline \multirow[t]{3}{*}{ Cerebrum } & {$\left[{ }^{18} \mathrm{~F}\right] \mathrm{FDG} /\left[{ }^{125} \mathrm{I}\right]$ iomazenil } & -0.7023 & 0.9419 \\
\hline & $\left.{ }^{18} \mathrm{~F}\right] \mathrm{FDG} /\left[^{99 \mathrm{~m}} \mathrm{Tc}\right] \mathrm{HMPAO}$ & -0.2578 & -0.9859 \\
\hline & $\left[{ }^{125} \mathrm{I}\right]$ iomazenil//[99 $\left.\mathrm{Tc}\right] \mathrm{HMPAO}$ & -0.1907 & -0.9847 \\
\hline \multirow[t]{3}{*}{ Cortex } & {$\left[{ }^{18} \mathrm{~F}\right] \mathrm{FDG} /\left[{ }^{125} \mathrm{I}\right]$ iomazenil } & -0.9341 & 0.9985 \\
\hline & {$\left[{ }^{18} \mathrm{~F}\right] \mathrm{FDG} /\left[^{99 \mathrm{~m}} \mathrm{Tc}\right] \mathrm{HMPAO}$} & -0.5212 & -0.9976 \\
\hline & $\left[{ }^{125} \mathrm{I}\right]$ iomazenil//[99m $\left.\mathrm{Tc}\right] \mathrm{HMPAO}$ & 0.2411 & -0.9925 \\
\hline \multirow[t]{3}{*}{ Hippocampus } & {$\left[{ }^{18} \mathrm{~F}\right] \mathrm{FDG} /\left[{ }^{125} \mathrm{I}\right]$ iomazenil } & -0.8004 & 0.8544 \\
\hline & $\left.\left[{ }^{18} \mathrm{~F}\right] \mathrm{FDG} / /^{99 \mathrm{~m}} \mathrm{Tc}\right] \mathrm{HMPAO}$ & -0.3207 & -0.9621 \\
\hline & {$\left[{ }^{125} \mathrm{I}\right]$ iomazenil/[ $\left[{ }^{99 \mathrm{~m}} \mathrm{Tc}\right] \mathrm{HMPAO}$} & -0.2260 & -0.9636 \\
\hline \multirow[t]{3}{*}{ Cerebellum } & {$\left[{ }^{18} \mathrm{~F}\right] \mathrm{FDG} /\left[{ }^{125} \mathrm{I}\right]$ iomazenil } & 0.2849 & 0.9775 \\
\hline & {$\left[{ }^{18} \mathrm{~F}\right] \mathrm{FDG} /\left[{ }^{99 \mathrm{~m}} \mathrm{Tc}\right] \mathrm{HMPAO}$} & -0.8212 & -0.8723 \\
\hline & $\left[{ }^{125} \mathrm{I}\right]$ iomazenil//[99m $\left.\mathrm{Tc}\right] \mathrm{HMPAO}$ & -0.8212 & -0.7495 \\
\hline
\end{tabular}

carried out on anesthetized mice to avoid introducing additional variability resulting from an awake uptake phase [40]. The opposite alterations in perfusion and $\left[{ }^{18} \mathrm{~F}\right] \mathrm{FDG}$ uptake could be explained by two mechanisms: neurovascular decoupling or the metabolic activity of microglia and infiltrating immune cells. Decoupling during inflammation has been reported in both human [41] and animal studies [42] but it would not fully explain the rise in $\left[{ }^{18}\right.$ F]FDG uptake we measured. Both SAE and the LPS model leads to an increased microglial activity and the infiltration of peripheral immune cells in the brain. These cells also express glucose transporters and can contribute to $\left[{ }^{18}\right.$ F]FDG PET signal during neuroinflammation [43] making them the most likely cause of the increased $\left[{ }^{18} \mathrm{~F}\right] \mathrm{FDG}$ uptake we observed.

In order to be able to image two isotopes with SPECT in the same animal at the same time, we used $\left[{ }^{125} \mathrm{I}\right]$ iodine. Mouse imaging with $\left[{ }^{125} \mathrm{I}\right]$ iodine is a well-established quantitative possibility even with minuscule injected activities such as $0.2 \mathrm{MBq}$ per animal [44-47]. For $\left[{ }^{125} \mathrm{I}\right]$ iodine containing radiopharmaceuticals, we used potassium 


\section{a}

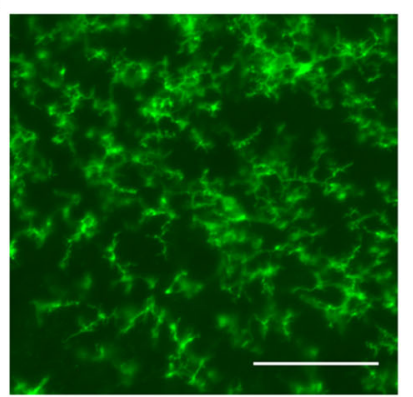

b

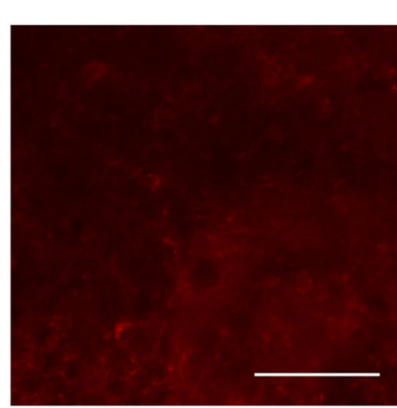

Control

e

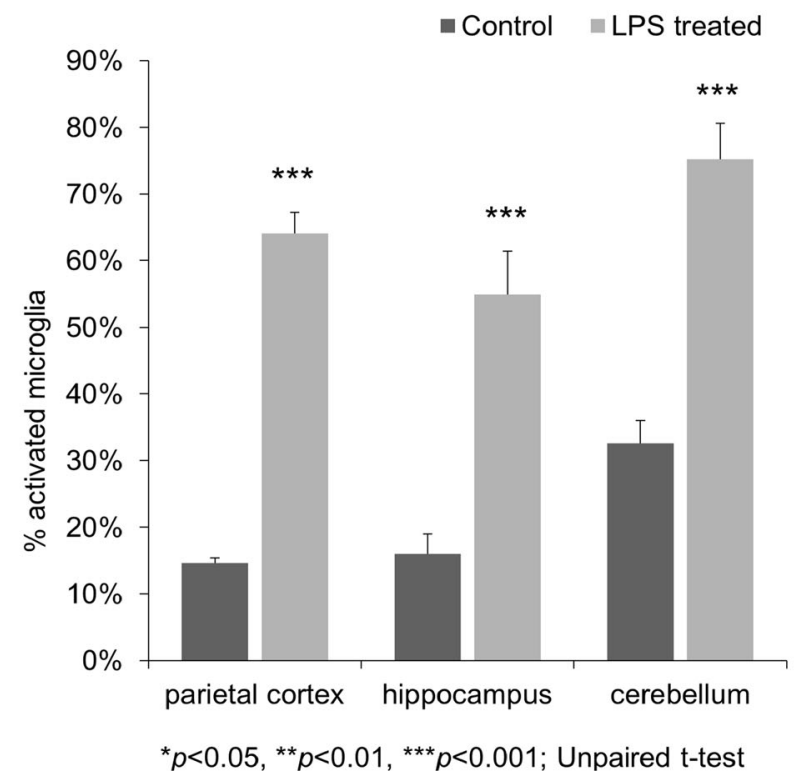

C

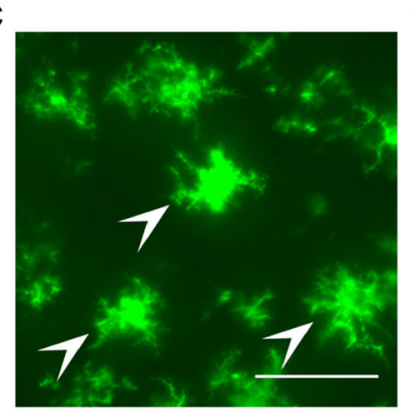

LPS treated
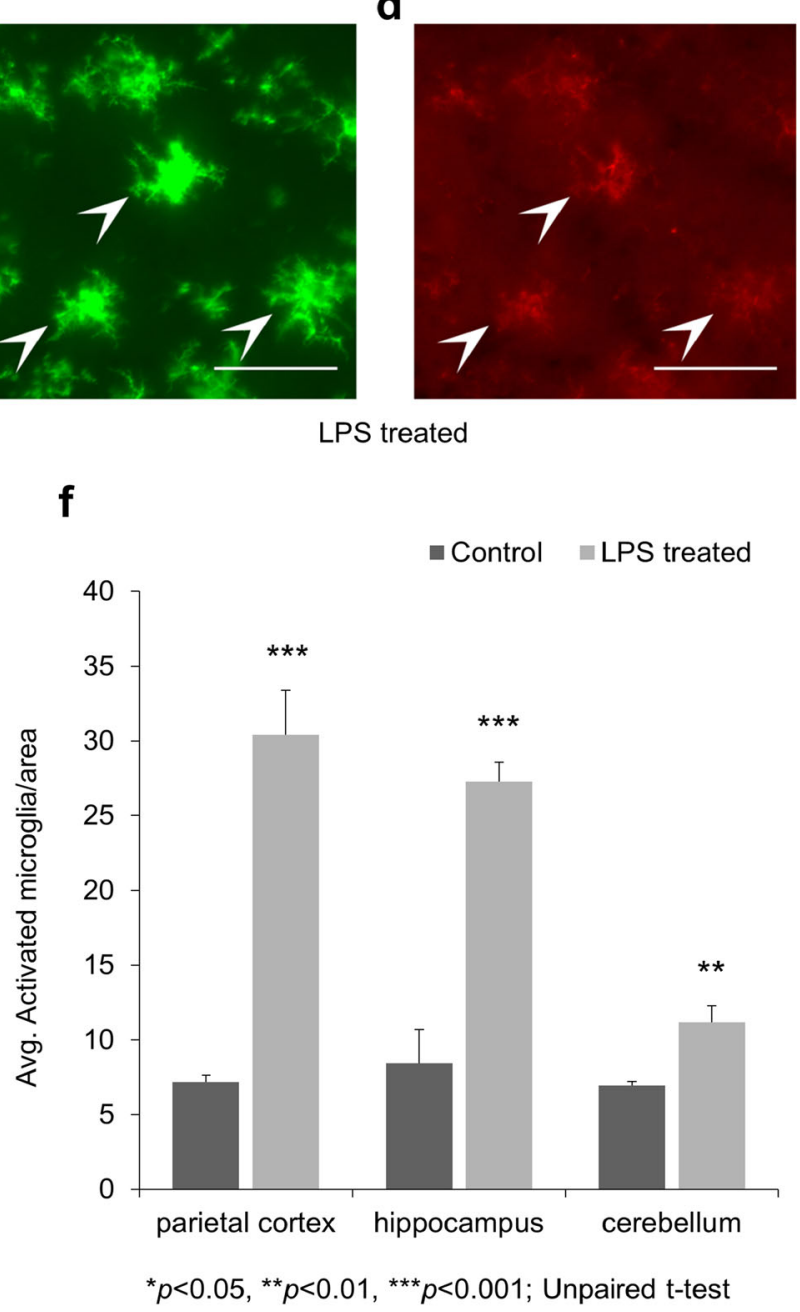

Fig. 6 P2Y12 and CD45 double-labeling immunohistochemistry before and after LPS treatment. Representative photomicrographs from the hippocampus. All scale bars correspond to $50 \mu \mathrm{m}$. a P2Y12 brain immunostaining of control animals reveals ramified, P2Y12+ microglia in all brain regions (parietal cortex, hippocampus, and cerebellum). $\mathbf{b}$ The CD45 immunostaining of the same area reveals very low CD45 immunoreactivity. c P2Y12 staining reveals activated microglia cells with enlarged cell bodies and thickened processes in LPS-treated animals (arrowheads). d Double labeling with CD45 shows the CD45 low expression of the corresponding cells (arrowheads). e The percentage of activated/all microglia based on morphology and CD45 expression. $\mathbf{f}$ The number of activated microglia per brain area.

perchlorate to competitively inhibit iodine uptake of different peripheral tissues via the sodium iodine symporter (NIS) $[48,49]$.

Neuronal damage and cell death has been previously described both in human SAE and animal models of sepsis [2]. Neuron loss could be the mechanism leading to longterm cognitive impairment observed in critically ill patients [50]. Radiolabeled iomazenil and flumazenil are widely regarded as nuclear medicine tracers indicating neuronal integrity and neuron loss [51-53]. Surprisingly, our measurements showed that $\left[{ }^{[25} \mathrm{I}\right]$ iomazenil, a partial inverse agonist of the central benzodiazepine receptor, has an increased uptake in the brains of LPS-treated mice. (Fig. 3a-c). In a previous study, Parente A. et al. investigated the possibility of experimental neuroinflammation influencing the cerebral pharmacokinetics of $\left[{ }^{11} \mathrm{C}\right]$ flumazenil [54]. They observed no significant differences in radiotracer uptake between control and herpes simplex encephalitis rats. Contrarily, our results suggest that brain $\left[{ }^{125} \mathrm{I}\right]$ iomazenil uptake (a SPECT analogue of $\left[{ }^{11} \mathrm{C}\right]$ flumazenil) can be directly influenced by neuroinflammation during the early phase of systemic inflammation. Several putative mechanisms could contribute to the increased uptake. $\mathrm{GABA}_{\mathrm{A}}$ receptors are present on microglia [55], astrocytes [56-58], and infiltrating immune cells $[59,60]$. Furthermore $\left[{ }^{125}\right.$ I]iomazenil can also bind to the peripheral benzodiazepine receptor (TSPO) with micromolar affinity which has an increased glial expression during 
neuroinflammation [61]. $\left[{ }^{125}\right.$ I]iomazenil as an ester type molecule can be easily degraded by tissue esterase [62]. The additionally injected neostigmine (cholinesterase enzyme blocker in order to enhance plasma stability of $\left[{ }^{125} \mathrm{I}\right]$ iomazenil) could have increased the availability of $\left[{ }^{125} \mathrm{I}\right]$ iomazenil in the brain making low affinity TSPO binding more likely. Since all of these non-neuronal mechanisms that arise during neuroinflammation can play a role in the measured signal, $\left[{ }^{125} \mathrm{I}\right]$ iomazenil is an unreliable marker of neuronal damage in the LPS model and also possibly other models of sepsis. On the other hand, these results raise important questions regarding the $\mathrm{GABA}_{\mathrm{A}}$ system during neuroinflammation and a potential role for $\left[{ }^{125} \mathrm{I}\right]$ iomazenil as an immune system-related radiotracer of neuroinflammation.

Various studies have confirmed the presumed role of TSPO as a marker of neuroinflammation [63, 64] based on its up-regulated expression on microglial cells, astrocytes, and increased ligand binding after neural damage [65] but its exact functional role is unknown [66]. In our experiments, we applied $\left[{ }^{125} \mathrm{I}\right]$ CLINME for TSPO imaging. In the LPStreated group, significantly enhanced $(p=0.05)$ $\left[{ }^{125} \mathrm{I}\right]$ CLINME uptake values were measured in the cerebrum, and a marked, but statistically not significant enhancement in the other brain regions of the treated group (Fig. 5a-c). The lack of significant results is most likely due to the low signal-to-noise ratio of our measurements resulting from the combination of low injected activity and small regions of interest. Due to the larger size of the cerebrum VOI, the noise has a lesser impact on the activity measured there. Elevated TSPO expression in LPS-induced systemic inflammation has also been observed in non-human primates [67] and human subjects [68].

The results of the correlation studies (Table 2) outline that the brain region-specific pairwise correlation of $\left[{ }^{125} \mathrm{I}\right]$ iomazenil, $\left[{ }^{99 \mathrm{~m}} \mathrm{Tc}\right] \mathrm{HMPAO}$, and $\left[{ }^{18} \mathrm{~F}\right] \mathrm{FDG}$ uptake values is different between the control and LPS-treated group. The brain region dependence of correlation coefficients is much lower in the LPS-treated animals than the controls. In healthy animals, $\left[{ }^{18} \mathrm{~F}\right] \mathrm{FDG},\left[{ }^{125} \mathrm{I}\right]$ iomazenil, and $\left[{ }^{99 \mathrm{~m}} \mathrm{Tc}\right]$ HMPAO uptake mostly depends on cerebral glucose metabolism, $\mathrm{GABA}_{\mathrm{A}}$ receptor density, and cerebral perfusion, respectively. In the LPS-treated animals, the highly positive correlation between $\left[{ }^{18} \mathrm{~F}\right] \mathrm{FDG}$ and $\left[{ }^{125} \mathrm{I}\right]$ iomazenil uptake in all investigated brain regions suggest that inflammatory processes could indeed influence both of these values as discussed earlier. Further supporting this hypothesis, microglia activation was also significantly elevated regardless of brain region (based on IHC and $\left[{ }^{125} \mathrm{I}\right]$ CLINME SPECT results). The highly negative correlations between $\left[{ }^{99 \mathrm{~m}} \mathrm{Tc}\right] \mathrm{HMPAO}$ and $\left[{ }^{18} \mathrm{~F}\right] \mathrm{FDG}$ or $\left[{ }^{125} \mathrm{I}\right]$ iomazenil also fit into this idea if we assume that cerebral hypoperfusion could indicate the severity of inflammation and thus correlate with the metabolic activity and activation state of microglia and infiltrating immune cells that positively contribute to $\left[{ }^{18} \mathrm{~F}\right] \mathrm{FDG}$ and $\left[{ }^{125} \mathrm{I}\right]$ iomazenil signal.
As there were no differences in ex vivo glutathione state, we presume time course of GSH-GSSG transformation seems to be too quick to separately measure GSH and GSSG levels by the applied Glutathione Detection Kit.

P2Y12 and CD45 double-labeling immunohistochemical (IHC) studies proved the activation of microglia in all the examined brain regions of the LPS-treated animals (Fig. 6). The metabotropic purinergic receptor P2Y12 is expressed by resting and activated microglia which can be used to distinguish them from other CNS cells or myeloid lineage cells (e.g., recruited leukocytes) [69, 70]. Although its expression levels were shown to highly depend on the activation and polarization states of microglia [49, 71], here it was used only to identify them and assess their morphology. CD45 is a cell surface glycoprotein expressed in all nucleated hematopoietic cells [72]. It has been shown that CD45 expression is up-regulated in activated microglia in different diseases and models [73-76]. By assessing the morphology and CD45 immunoreactivity of microglia, we were able to distinguish between activated and resting cells with a high degree of certainty.

\section{Conclusion}

In conclusion, we have described the brain region-specific uptake of a set of widely used radiotracers $\left(\left[{ }^{99 \mathrm{~m}} \mathrm{Tc}\right] \mathrm{HMPAO}\right.$, $\left[{ }^{125} \mathrm{I}\right]$ iomazenil, $\left.\left[{ }^{18} \mathrm{~F}\right] \mathrm{FDG}\right)$ during the early phase of LPSinduced murine systemic inflammation. Our results suggest that inflammatory processes can directly contribute to the uptake of $\left[{ }^{125} \mathrm{I}\right]$ iomazenil and $\left[{ }^{18} \mathrm{~F}\right] \mathrm{FDG}$ masking the neuroinflammation-induced neuron damage and hypometabolism of neural tissue, respectively. Furthermore, we have showed that $\left[{ }^{99 \mathrm{~m}} \mathrm{Tc}\right]$ HMPAO and $\left[{ }^{125 \mathrm{I}}\right]$ CLINME can be used to detect cerebral hypoperfusion and microglia activation, respectively, as early as $4 \mathrm{~h}$ following the i.v. injection of LPS. Further investigation of the metabolic activity of different brain cells and the status of the GABA receptor system of infiltrating immune cells would be necessary to determine the exact source of the measured signal differences during the early phase of systemic inflammation.

Acknowledgements. This work was funded in part by INMiND (HEALTH.2011.2.2.1-2 No.278850) of FP7 and by VKSZ-14-1-20050151. We thank Mediso Ltd. for technical background of NanoSPECT/CT Plus and nanoScan PET/MRI. K Szigeti was supported by the Janos Bolyai Research Fellowship program of the Hungarian Academy of Science.

\section{Compliance with Ethical Standards}

\section{Conflict of Interest}

The authors declare that they have no conflict of interest.

Open Access This article is distributed under the terms of the Creative Commons Attribution 4.0 International License (http://creativecommons.org/licenses/by/4.0/), which permits unrestricted use, distribution, and reproduction in any medium, provided you give appropriate credit to the original author(s) and the source, provide a link to the Creative Commons license, and indicate if changes were made. 


\section{References}

1. Chaudhry N, Duggal AK (2014) Sepsis associated encephalopathy. Adv Med 2014:762320

2. Zampieri FG, Park M, Machado FS, Azevedo LC (2011) Sepsisassociated encephalopathy: not just delirium. Clinics 66:1825-1831

3. Ning Q, Liu Z, Wang X, Zhang R, Zhang J, Yang M, Sun H, Han F, Zhao W, Zhang X (2017) Neurodegenerative changes and neuroapoptosis induced by systemic lipopolysaccharide administration are reversed by dexmedetomidine treatment in mice. Neurol Res 39:357366

4. Laye S, Parnet P, Goujon E, Dantzer R (1994) Peripheral administration of lipopolysaccharide induces the expression of cytokine transcripts in the brain and pituitary of mice. Brain Res Mol Brain Res 27:157-162

5. Gabellec MM, Griffais R, Fillion G, Haour F (1995) Expression of interleukin 1 alpha, interleukin 1 beta and interleukin 1 receptor antagonist mRNA in mouse brain: regulation by bacterial lipopolysaccharide (LPS) treatment. Brain Res Mol Brain Res 31:122-130

6. Pitossi F, del Rey A, Kabiersch A, Besedovsky H (1997) Induction of cytokine transcripts in the central nervous system and pituitary following peripheral administration of endotoxin to mice. J Neurosci Res 48:287-298

7. Ban E, Haour F, Lenstra R (1992) Brain interleukin 1 gene expression induced by peripheral lipopolysaccharide administration. Cytokine $4: 48-54$

8. Hoogland IC, Houbolt C, van Westerloo DJ et al (2015) Systemic inflammation and microglial activation: systematic review of animal experiments. J Neuroinflamm 12:114

9. Qin L, Wu X, Block ML, Liu Y, Breese GR, Hong JS, Knapp DJ, Crews FT (2007) Systemic LPS causes chronic neuroinflammation and progressive neurodegeneration. Glia 55:453-462

10. Ming Z, Wotton CA, Appleton RT, Ching JC, Loewen ME, Sawicki G, Bekar LK (2015) Systemic lipopolysaccharide-mediated alteration of cortical neuromodulation involves increases in monoamine oxidaseA and acetylcholinesterase activity. J Neuroinflamm 12:37

11. Abdel-Salam OM, Youness ER, Mohammed NA et al (2014) Citric acid effects on brain and liver oxidative stress in lipopolysaccharidetreated mice. J Med Food 17:588-598

12. Varatharaj A, Galea I (2017) The blood-brain barrier in systemic inflammation. Brain Behav Immun 60:1-12

13. Zhou H, Andonegui G, Wong CH, Kubes P (2009) Role of endothelial TLR4 for neutrophil recruitment into central nervous system microvessels in systemic inflammation. J Immunol 183:5244 5250

14. Bohatschek M, Werner A, Raivich G (2001) Systemic LPS injection leads to granulocyte influx into normal and injured brain: effects of ICAM-1 deficiency. Exp Neurol 172:137-152

15. Sharshar T, Gray F, Lorin de la Grandmaison G et al (2003) Apoptosis of neurons in cardiovascular autonomic centres triggered by inducible nitric oxide synthase after death from septic shock. Lancet 362:1799_ 1805

16. Mazeraud A, Pascal Q, Verdonk F, Heming N, Chrétien F, Sharshar T (2016) Neuroanatomy and physiology of brain dysfunction in sepsis. Clin Chest Med 37:333-345

17. Burkhart CS, Siegemund M, Steiner LA (2010) Cerebral perfusion in sepsis. Crit Care 14:215

18. Bozza FA, D'Avila JC, Ritter C et al (2013) Bioenergetics, mitochondrial dysfunction, and oxidative stress in the pathophysiology of septic encephalopathy. Shock 39(Suppl 1):10-16

19. Pulli B, Chen JW (2014) Imaging neuroinflammation-from bench to bedside. J Clin Cell Immunol 5:226

20. Stubbs DJ, Yamamoto AK, Menon DK (2013) Imaging in sepsisassociated encephalopathy-insights and opportunities. Nat Rev Neurol 9:551-561

21. Chang JM, Lee HJ, Goo JM, Lee HY, Lee JJ, Chung JK, Im JG (2006) False positive and false negative FDG-PET scans in various thoracic diseases. Korean J Radiol 7:57-69

22. Kapucu OL, Nobili F, Varrone A, Booij J, Vander Borght T, Någren K, Darcourt J, Tatsch K, van Laere KJ (2009) EANM procedure guideline for brain perfusion SPECT using ${ }^{99 \mathrm{~m}}$ Tc-labelled radiopharmaceuticals, version 2. Eur J Nucl Med Mol Imaging 36:20932102
23. Abiko K, Ikoma K, Shiga T, Katoh C, Hirata K, Kuge Y, Kobayashi $\mathrm{K}$, Tamaki N (2017) I-123 iomazenil single photon emission computed tomography for detecting loss of neuronal integrity in patients with traumatic brain injury. EJNMMI Res 7:28

24. Saito H, Magota K, Zhao S, Kubo N, Kuge Y, Shichinohe H, Houkin K, Tamaki N, Kuroda S (2013) ${ }^{123}$ I-iomazenil single photon emission computed tomography visualizes recovery of neuronal integrity by bone marrow stromal cell therapy in rat infarct brain. Stroke 44:28692874

25. Toyama H, Matsumura K, Nakashima H, Takeda K, Takeuchi A, Koga S, Yoshida T, Ichise M (1998) Characterization of neuronal damage by iomazenil binding and cerebral blood flow in an ischemic rat model. Ann Nucl Med 12:267-273

26. Hatazawa J, Shimosegawa E (1998) Imaging neurochemistry of cerebrovascular disease with PET and SPECT. Q J Nucl Med 42:193-198

27. Mattner F, Quinlivan M, Greguric I et al (2015) Radiosynthesis, in vivo biological evaluation, and imaging of brain lesions with [123I]-CLINME, a new SPECT tracer for the translocator protein. Dis Markers 2015:729698

28. Tai YF, Piccini P (2004) Applications of positron emission tomography (PET) in neurology. J Neurol Neurosurg Psychiatry 75:669-676

29. Kobayashi K, Yamanaka H, Fukuoka T, Dai Y, Obata K, Noguchi K (2008) P2Y12 receptor upregulation in activated microglia is a gateway of p38 signaling and neuropathic pain. J Neurosci 28:28922902

30. Swiatkowski P, Murugan M, Eyo UB, Wang Y, Rangaraju S, Oh SB, $\mathrm{Wu}$ LJ (2016) Activation of microglial P2Y12 receptor is required for outward potassium currents in response to neuronal injury. Neuroscience 318:22-33

31. Greter M, Lelios I, Croxford AL (2015) Microglia versus myeloid cell nomenclature during brain inflammation. Front Immunol 6:249

32. Denes A, Coutts G, Lenart N et al (2015) AIM2 and NLRC4 inflammasomes contribute with ASC to acute brain injury independently of NLRP3. Proc Natl Acad Sci U S A 112:4050-4055

33. Szalay G, Martinecz B, Lenart N et al (2016) Microglia protect against brain injury and their selective elimination dysregulates neuronal network activity after stroke. Nat Commun 7:11499

34. Bonnini S, Corain L, Marozzi M, Salmaso L (2014) One- and twosample location problems, tests for symmetry and tests on a single distribution. In: Balding DJ et al (eds) Nonparametric hypothesis testing: rank and permutation methods with application in R. John Wiley \& Sons, Chichester, pp 1-37

35. Schramm P, Klein KU, Falkenberg L, Berres M, Closhen D, Werhahn KJ, David M, Werner C, Engelhard K (2012) Impaired cerebrovascular autoregulation in patients with severe sepsis and sepsisassociated delirium. Crit Care 16:R181

36. Berg RMG, Plovsing RR, Bailey DM, Holstein-Rathlou NH, Møller K (2015) The dynamic cerebral autoregulatory adaptive response to noradrenaline is attenuated during systemic inflammation in humans. Clin Exp Pharmacol Physiol 42:740-746

37. Taccone FS, Scolletta S, Franchi F, Donadello K, Oddo M (2013) Brain perfusion in sepsis. Curr Vasc Pharmacol 11:170-186

38. Wilson JX, Young GB (2003) Progress in clinical neurosciences: sepsis-associated encephalopathy: evolving concepts. Can J Neurol Sci 30:98-105

39. Semmler A, Hermann S, Mormann F, Weberpals M, Paxian SA, Okulla T, Schäfers M, Kummer MP, Klockgether T, Heneka MT (2008) Sepsis causes neuroinflammation and concomitant decrease of cerebral metabolism. J Neuroinflammation 5:38

40. Byrnes KR, Wilson CM, Brabazon F et al (2014) FDG-PET imaging in mild traumatic brain injury: a critical review. Front Neuroenerg 5:13

41. Rosengarten B, Krekel D, Kuhnert S, Schulz R (2012) Early neurovascular uncoupling in the brain during community acquired pneumonia. Crit Care 16:R64

42. Rosengarten B, Hecht M, Auch D, Ghofrani HA, Schermuly RT, Grimminger F, Kaps M (2007) Microcirculatory dysfunction in the brain precedes changes in evoked potentials in endotoxin-induced sepsis syndrome in rats. Cerebrovasc Dis 23:140-147

43. Backes H, Walberer M, Ladwig A, Rueger MA, Neumaier B, Endepols H, Hoehn M, Fink GR, Schroeter M, Graf R (2016) Glucose consumption of inflammatory cells masks metabolic deficits in the brain. NeuroImage 128:54-62 
44. Hong SY, Tobias G, Al-Jamal KT et al (2010) Filled and glycosylated carbon nanotubes for in vivo radioemitter localization and imaging. Nat Mater 9:485-490

45. Jang B, Park S, Kang SH, Kim JK, Kim SK, Kim IH, Choi Y (2012) Gold nanorods for target selective SPECT/CT imaging and photothermal therapy in vivo. Quant Imaging Med Surg 2:1-11

46. Mathe D, Horvath I, Szigeti K et al (2013) In vivo SPECT and ex vivo autoradiographic brain imaging of the novel selective CB1 receptor antagonist radioligand $\left[{ }^{125} \mathrm{I}\right] \mathrm{SD} 7015$ in $\mathrm{CB} 1$ knock-out and wildtype mouse. Brain Res Bull 91:46-51

47. Su N, Dang Y, Liang G, Liu G (2015) Iodine-125-labeled cRGD-gold nanoparticles as tumor-targeted radiosensitizer and imaging agent. Nanoscale Res Lett 10:160

48. Yu KO, Narayanan L, Mattie DR, Godfrey RJ, Todd PN, Sterner TR, Mahle DA, Lumpkin MH, Fisher JW (2002) The pharmacokinetics of perchlorate and its effect on the hypothalamus-pituitary-thyroid axis in the male rat. Toxicol Appl Pharmacol 182:148-159

49. Tonacchera M, Pinchera A, Dimida A, Ferrarini E, Agretti P, Vitti P, Santini F, Crump K, Gibbs J (2004) Relative potencies and additivity of perchlorate, thiocyanate, nitrate, and iodide on the inhibition of radioactive iodide uptake by the human sodium iodide symporter. Thyroid 14:1012-1019

50. Pandharipande PP, Girard TD, Ely EW (2014) Long-term cognitive impairment after critical illness. N Engl J Med 370:185-186

51. Muller V, Saur D, Klutmann S et al (2002) Experience with ${ }^{123} \mathrm{I}$ iomazenil SPECT in acute cerebral infarction. Nucl Med Commun 23:1191-1196

52. Nakagawara J, Kamiyama K, Takahashi M, Nakamura H (2013) Cortical neuron loss in post-traumatic higher brain dysfunction using ${ }^{123}$ I-iomazenil SPECT. Acta Neurochir Suppl 118:245-250

53. Rasmussen LS, Sperling B, Abildstrom HH, Moller JT (2002) Neuron loss after coronary artery bypass detected by SPECT estimation of benzodiazepine receptors. Ann Thorac Surg 74:1576-1580

54. Parente A, Vallez Garcia D, Shoji A et al (2017) Contribution of neuroinflammation to changes in $\left[{ }^{11} \mathrm{C}\right]$ flumazenil binding in the rat brain: evaluation of the inflamed pons as reference tissue. Nucl Med Biol 49:50-56

55. Liu H, Leak RK, Hu X (2016) Neurotransmitter receptors on microglia. Stroke Vasc Neurol 1:52-58

56. Fraser DD, Mudrick-Donnon LA, MacVicar BA (1994) Astrocytic GABA receptors. Glia 11:83-93

57. Lee M, Schwab C, McGeer PL (2011) Astrocytes are GABAergic cells that modulate microglial activity. Glia 59:152-165

58. Yoon BE, Woo J, Lee CJ (2012) Astrocytes as GABA-ergic and GABA-ceptive cells. Neurochem Res 37:2474-2479

59. Barragan A, Weidner JM, Jin Z, Korpi ER, Birnir B (2015) GABAergic signalling in the immune system. Acta Physiol 213:819-827

60. Nigam R, El-Nour H, Amatya B, Nordlind K (2010) GABA and GABA(A) receptor expression on immune cells in psoriasis: a pathophysiological role. Arch Dermatol Res 302:507-515

61. Kassiou M, Meikle SR, Banati RB (2005) Ligands for peripheral benzodiazepine binding sites in glial cells. Brain Res Rev 48:207-210

62. Bahar FG, Ohura K, Ogihara T, Imai T (2012) Species difference of esterase expression and hydrolase activity in plasma. J Pharm Sci 101:3979-3988
63. Wilms H, Claasen J, Rohl C et al (2003) Involvement of benzodiazepine receptors in neuroinflammatory and neurodegenerative diseases: evidence from activated microglial cells in vitro. Neurobiol Dis $14: 417-424$

64. Banati RB, Newcombe J, Gunn RN, Cagnin A, Turkheimer F, Heppner F, Price G, Wegner F, Giovannoni G, Miller DH, Perkin GD, Smith T, Hewson AK, Bydder G, Kreutzberg GW, Jones T, Cuzner ML, Myers R (2000) The peripheral benzodiazepine binding site in the brain in multiple sclerosis: quantitative in vivo imaging of microglia as a measure of disease activity. Brain 123:2321-2337

65. Chen MK, Guilarte TR (2008) Translocator protein $18 \mathrm{kDa}$ (TSPO): molecular sensor of brain injury and repair. Pharmacol Ther 118:1-17

66. Banati RB (2002) Visualising microglial activation in vivo. Glia 40:206-217

67. Hannestad J, Gallezot JD, Schafbauer T, Lim K, Kloczynski T, Morris ED, Carson RE, Ding YS, Cosgrove KP (2012) Endotoxin-induced systemic inflammation activates microglia: $\left[{ }^{11} \mathrm{C}\right] \mathrm{PBR} 28$ positron emission tomography in nonhuman primates. NeuroImage 63(1):232-239

68. Sandiego CM, Gallezot JD, Pittman B, Nabulsi N, Lim K, Lin SF, Matuskey D, Lee JY, O'Connor KC, Huang Y, Carson RE, Hannestad J, Cosgrove KP (2015) Imaging robust microglial activation after lipopolysaccharide administration in humans with PET. Proc Natl Acad Sci U S A 112:12468-12473

69. Haynes SE, Hollopeter G, Yang G, Kurpius D, Dailey ME, Gan WB, Julius D (2006) The P2Y12 receptor regulates microglial activation by extracellular nucleotides. Nat Neurosci 9:1512-1519

70. Butovsky O, Jedrychowski MP, Moore CS, Cialic R, Lanser AJ, Gabriely G, Koeglsperger T, Dake B, Wu PM, Doykan CE, Fanek Z, Liu LP, Chen Z, Rothstein JD, Ransohoff RM, Gygi SP, Antel JP, Weiner HL (2014) Identification of a unique TGF-beta-dependent molecular and functional signature in microglia. Nat Neurosci 17:131143

71. Moore CS, Ase AR, Kinsara A, Rao VTS, Michell-Robinson M, Leong SY, Butovsky O, Ludwin SK, Séguéla P, Bar-Or A, Antel JP (2015) P2Y12 expression and function in alternatively activated human microglia. Neurol Neuroimmunol Neuroinflamm 2:e80

72. Trowbridge IS, Thomas ML (1994) CD45: an emerging role as a protein tyrosine phosphatase required for lymphocyte activation and development. Annu Rev Immunol 12:85-116

73. Cosenza-Nashat MA, Kim MO, Zhao ML, Suh HS, Lee SC (2006) CD45 isoform expression in microglia and inflammatory cells in HIV1 encephalitis. Brain Pathol 16:256-265

74. Akiyama H, Ikeda K, Katoh M, McGeer EG, McGeer PL (1994) Expression of MRP14, 27E10, interferon-alpha and leukocyte common antigen by reactive microglia in postmortem human brain tissue. J Neuroimmunol 50:195-201

75. Melief J, Koning N, Schuurman KG, van de Garde MDB, Smolders J, Hoek RM, van Eijk M, Hamann J, Huitinga I (2012) Phenotyping primary human microglia: tight regulation of LPS responsiveness. Glia 60:1506-1517

76. Chen Z, Jalabi W, Shpargel KB, Farabaugh KT, Dutta R, Yin X, Kidd GJ, Bergmann CC, Stohlman SA, Trapp BD (2012) Lipopolysaccharide-induced microglial activation and neuroprotection against experimental brain injury is independent of hematogenous TLR4. J Neurosci 32:11706-11715 